\title{
The Mediative Role of Family Socioeconomic Status in the Relationship Between Parental Attachment and Deviant Behaviour Among Secondary School Students in Homabay County Kenya
}

\author{
Dorothy Anyango Aute \\ Department of Psychology, Masinde Muliro University of Science and Technology, Kakamega, Kenya
}

Email address:

auteagai@yahoo.com

\section{To cite this article:}

Dorothy Anyango Aute. The Mediative Role of Family Socioeconomic Status in the Relationship Between Parental Attachment and Deviant Behaviour Among Secondary School Students in Homabay County Kenya. Science Journal of Education. Vol. 8, No. 2, 2020, pp. $32-40$. doi: $10.11648 /$ j.sjedu. 20200802.11

Received: March 18, 2020; Accepted: April 7, 2020; Published: April 28, 2020

\begin{abstract}
Deviant behaviour among secondary school students is exhibited in all schools across the world. Being adolescents, secondary school students tend to experiment a lot and as a result they often find themselves on the wrong side of the law sometimes not knowing how. A child's behaviour is modeled at home by the parents or the primary caregivers whose parental behaviour also depends on other factors. Some of these factors include family socioeconomic status. Parents who experience a lot of economic strain find it difficult to create a friendly parenting environment at home and consequently the attachment between the parent and the child is ensnared and this further contributes negatively to the behaviour of the child. The consequences of deviant behaviour may be devastating. They may include; destruction of property, early pregnancy, HIV and aids infection, school dropout and even death. The objective of this study was; to determine the mediative role of family socioeconomic status in the relationship between parental attachment and deviant behaviour among secondary school students in Homa bay County. The study was guided by parental attachment theory by John Bowlby and Mary Ainsworth which provided a conceptual link between parental attachment and deviance together with structural strain theory by Robert Merton which provided a conceptual link between socioeconomic status and parental attachment. The study used a correlational design and the target population included all the form two students from Homa bay County. From a population of 20,160 students a sample of 512 students was randomly selected to take part in the study. The principals, deputies, HODs, and PA representatives were purposively sampled. Data was collected through questionnaires, structured and unstructured interviews, focus group discussions and analysis of documents. The validity of the instruments was ascertained by experts and through piloting while the reliability was tested using the split half method and the level of confidence was $\alpha \leq 0.05$. Data was analyzed both quantitatively and qualitatively. The findings revealed a very strong significant correlation between SES and parental attachment $(\mathrm{r}=.714)$. The study recommends that the County government of Homa bay should come up with effective poverty eradication measures in order to improve the living standards of the families in Homa bay County. The study also recommends that the county government of Homa bay should introduce free and active adult education in the County and build such centers within the county.
\end{abstract}

Keywords: Mediative Role, Family SES, Parental Attachment, Deviant Behaviour

\section{Introduction}

A school is a unit which consists of a number of compartments which include the students' fraternity, the workers, the teachers, parents, the board of management and the community around the school. The success of a school is highly dependent on the contribution of each compartment and therefore students' discipline is a major contributor. Studies have proved that the discipline of a child is associated to the kind of attachment that exists between the child and the parents with most of them indicating a positive 
relationship between secure parental attachment and qualities like authenticity, bravery, high academic performance, high self esteem, responsible sexual behavior and participation in co-curriculum activities. Lim et al [13], Dimbuene and Defo [7], Yesu and Hardwood [37], Shute et al [32], Simba et al [30], Akwalu [1], Rafiq et al [25], Ngai [22] and Robin [27]. Some studies have also revealed a positive relationship between insecure parental attachment and adolescents' delinquency, low self esteem, verbal aggression, violent behaviour and risky sexual behavior. Poipoi et al [24], Tadesse et al [34], Borhani [4], Mutie [20] and Sanne et al [28]. Further still, some studies have revealed a negative correlation between secure parental attachment and deviant behaviour. Aute, [3]. When a parent develops an appropriate attachment with the child, the two will seek proximity to each other and hence the child will feel free to share with the parents especially concerning the challenges of adolescence. This attachment with parents would also help the child develop a proper mental representation of self and others and consequently shape how they regulate their emotions, thoughts and behaviour Aute, [3].

The discipline of a child in school depends on the comfort provided by the parents in the home environment and in school. Poor parents experience a lot of social and economic strain as they struggle to provide the very basic needs for their families and this denies them a chance to form secure attachment with their children in order to provide the required guidance. It is unfortunate that a large number of students from Homabay County come from underprivileged homes that are unable to provide them with all the resources they need in order to excel in school and due to the poverty rate in Homabay County the students are poorly attached to their parents. Whereas rich parents can provide adequate comfort at home and in school, children from poor families may hardly afford such privileges Yunus \& Dahlan, [38]. In Kenya, the government insists on $100 \%$ transition from primary school to secondary school but the challenge is that the government does not take care of the welfare of the child while in school apart from subsidizing the tuition fees and providing books. Consequently some students get involved in deviant behaviour in an attempt to achieve comfort, some lose hope and become pessimists, some do come up with new strategies of achieving comfort which may include unlawful means or worse still some rebel against the existing authorities and become hobos and revolutionists.

\subsection{Theoretical Framework}

This study adopted the parental attachment theory by Bowlby and Ainsworth [5] because this theory elaborates the various types of parental attachment and their consequences on the development of the child. According to this theory securely attached individuals show a balance between health connections to others and self reliance. Such individuals are associated with less involvement in deviance and enhanced coping strategies. This theory provided an important conceptual link between parent adolescent relationship and deviant behaviour
The structural theory by Merton [17] states that the laid down societal structures and their expectations may subject individuals to mental strain resulting to crime. Most poor parents experience a lot of such strain in their attempt to be good parents and to create appropriate attachment with their children. It is always every parent's dream to bring up their children in the best way possible and to be responsive to all the needs of their children at the right time in order to cultivate a secure attachment with their children. However, socioeconomic challenges pose a threat to the attachment between parents and their children. In this study, the structural strain theory provided a conceptual link between parental attachment and family socioeconomic status. According to Merton [17], the social strain that people experience in a community dictates the way they behave. Thus people either conform to the societal values despite the strain, invent new strategies of achieving stability, become pessimists and lose hope of ever becoming better, reject cultural goals and the means of achieving them or rebel and become radicals Merton [17]. When parents experience strain in their parenting environment, some may invent new strategies of parenting which may have detrimental effects on the behaviour of the children. Others reject their children and even become violent towards their children so that they are not bothered by the parental obligations.

\subsection{Area of Study}

Being situated along the lake, the main economic activity in Homa bay County is fishing. This implies that most parents spend most of their time either in the lake as fishermen or in the markets as fish mongers thus interfering with the attachment between parents and their children. Due to the presence of hyacinth in Lake Victoria, the population of fish is reduced to an extent that it can no longer sustain the livelihood of the residents of Homa bay County. Homa bay County is the poorest county in Nyanza region, Kenya, being ranked number 15 in the whole country with a poverty rate of $44.1 \%$. Apart from being the leading in poverty in Nyanza region, Homa bay County is the leading in HIV/ AIDS infection and also number two in the whole country in teenage pregnancy. Thus the purpose of this study was to establish the mediative role of family SES in the relationship between parental attachment and deviant behaviour among secondary school students in Homabay County.

\section{Research Methodology}

This study used a correlational study design and data was analyzed both quantitatively and qualitatively. The target population in the study comprised of form two students from all the secondary schools in Homa bay County. Two sub counties within the county with a population of 80 secondary schools and 5,120 form two students were randomly selected to take part in the study. The representative sample of students was 512 students from 8 schools being $10 \%$ of 5120 students and 80 schools respectively. 


\subsection{Sampling Procedure}

A sample is a segment of the population that is used to make conclusions regarding the whole population Mertens [16]. The schools were proportionally stratified into boarding girls' only, boarding boys' only and mixed day and boarding secondary schools. This helped the researcher to reach the required representation from the segments in the population and ensured that the existing sub groups are reproduced in the sample. There were $27(8.57 \%)$ boarding girls' schools, $35(11.11 \%)$ boarding boys' schools and $253(80.31 \%)$ mixed day and boarding secondary schools. Sample students consisted of 411 students from mixed day and boarding secondary schools, 44 students from girls' schools and 57 students from boys' schools. The principals, deputy principals and guidance and counseling HODs and parents' representatives (PA) were purposively picked from each school in the sample. These were picked as they had the relevant information with respect to the objective of the study. This information is further captured in tables 1 and 2.

Using Slovin's equation the sample size was determined using the following formula Mugenda and Mugenda [19].

$$
n=\frac{N}{1+N(e)^{2}}
$$

Where $n=$ sample,
$\mathrm{N}=$ the size of the population and

$\mathrm{e}=$ the margin error.

According to Mugenda and Mugenda [19] the margin of error is the statistical concept which expresses the difference between the population and the characteristics of the sample, although the sample emanates from that population. The confidence level for this study was at $95 \%$ (0.95). If a sample is picked from the target population 100 times then at least $95 \%$ of the samples will portray the qualities of the population Ngwiri, Mukulu \& Mputhia, [23]. The margin of error for this study was therefore $5 \%$.

$$
\text { Sample proportion }(\%)=\frac{512}{5120} \times 100=10.00 \%
$$

Girls' boarding schools were $\frac{27}{315} \times 100=8.57 \%$

Boys' boarding schools $\frac{35}{315} \times 100=11.11 \%$

Mixed day and boarding schools $\frac{253}{315} \times 100=80.31 \%$

Girls' schools $=\frac{8.57}{100} \times 512=44$ students

Boys' schools $=\frac{11.11}{100} \times 512=57$ students

Mixed day and boarding $=\frac{80.31}{100} \times 512=411$ students

Total 512 students

Table 1. Sampling Matrix for School Type.

\begin{tabular}{lllll}
\hline Selected school type & Sampling design & Target population & Sample size & Percentage \\
\hline Boys only & Stratified sampling & 9 & 1 & $11.11 \%$ \\
Girls only & Stratified sampling & 7 & 1 & $8,57 \%$ \\
Mixed day and boarding & Stratified sampling & 64 & 6 & $80.31 \%$ \\
Total & & 80 & 8 & $100 \%$ \\
\hline
\end{tabular}

Source: Author'sdata

Table 2. Sample Matrix for Respondents.

\begin{tabular}{lllll}
\hline Sample unit & Sampling design & Target population & Sample size & Percentage \\
\hline Schools & Random sampling & 80 & 8 & $10 \%$ \\
Principals & Purposive sampling & 80 & 8 & $10 \%$ \\
HOD G\&C & Purposive sampling & 80 & 8 & $10 \%$ \\
Students & Random sampling & 5,120 & 512 & $10 \%$ \\
PA & Purposive sampling & 80 & 8 & $10 \%$ \\
Deputy Principals & Purposive sampling & 80 & 8 & $10 \%$ \\
\hline
\end{tabular}

Source: Author's data

\subsection{Research Instruments}

In this study data was collected using the parental attachment questionnaires for measuring the attachment styles and socioeconomic status questionnaires for measuring family socioeconomic status. Interview schedules, focus group discussions and document analysis were used to collect qualitative data.

\subsection{Pilot Study}

The tools were piloted in order to detect any ambiguity and correct them. The researcher administered a set of structured questionnaires and interview guides to students, parents and teachers not included in the sample schools. This helped to examine the appropriateness of the instruments and to get a rough estimate of the time required for the study. This further helped the researcher to make any necessary changes to the instruments with the help of experts from MMUST. For example, specific words which were misinterpreted by the pilot participants were replaced by more familiar words. The interview schedules were flexible enough and ensured that no relevant information was left out. To evaluate the worth of a study, its trustworthiness must be established. Lincoln and Guba [15] assert that trustworthiness is established when findings of the study reflect the true situation described by the respondents. They propose a variety of strategies to 
ensure trustworthiness. These include credibility- trust in the findings, transferability showing that the findings can be relevant in other contexts, dependability - this also refers to the consistency of the findings, confirmability- ensuring that the findings reflect the responses of the participants and not the wishes of the researcher Shenton, [30].

\subsection{Validity and Reliability of Research Instruments}

For a research instrument to produce trustworthy results, its validity and reliability must be tested in order to verify if the instrument actually measures what it purports to measure and whether the results are replicable.

\subsection{Validity of the Instruments}

Validity refers to the ability of the instrument in question to assess what it ought to in order to allow the researcher to draw accurate conclusions Ngwiri et al, [23]. The validity of the instruments was ascertained by expert supervisors of MMUST. Content validity is a judgmental act where experts check whether the items are relevant to the objectives of the study as well as the wording, formatting and scoring of the instrument Mertens, [16]. This was achieved by making sure that the items were highly structured to avoid ambiguity (content validity), whether the items needed to be rephrased for correctness, appropriateness for time schedules for completing it, the formatting and the scoring of the instrument. Internal validity was taken care of through triangulation of instruments.

\subsection{Reliability of the Instruments}

Reliability is a measure of the consistency of the results produced by a research instrument after repeated measurements are taken of the same subjects under similar conditions Ngwiri et al, [23]. Reliability of the questionnaires was determined by the internal consistency method which demands that the instrument or test to be run once only through the split half method contrary to the test retest method and the equivalent forms reliability which require the test or the instrument to be administered twice. The split half method eliminates chances of error due to differing conditions. In this research, the test items were divided into two with each half matched in terms of items or item difficulty and content. The halves were marked separately. The marks obtained in each half was correlated with the other. Any student's mark on one half should match his or her marks in the other half. This was calculated using the Spearman's- Brown formula.

$$
\text { Reliability }=\frac{2 r}{1+r}
$$

This calculation required a correlation coefficient to be calculated for example, Spearman's rank order or a Pearson's product moment correlation. Kothari [12] argues that a reliability coefficient of 0.6 will be considered appropriate similar to Mugenda and Mugenda [19] who also argue that a reliability coefficient of 0.80 or more means there is a high degree of reliability. The calculation of the split half coefficient was done with all the questionnaires and the results indicated that parental attachment questionnaire 0.763 , deviant behavior variety scale 0.764 , socioeconomic status questionnaire 0.763 and finally IERS 0.689. The measurement procedure was considered to demonstrate split half reliability since the two sets of scores were highly correlated.

\section{Data Collection Procedures}

The researcher obtained a letter authorizing her to conduct the field study from the faculty of education MMUST. The letter also introduced the researcher and the study to be undertaken. A permit to carry out the study was also obtained from the National Council of Science Technology and Innovation (NACOSTI). The researcher developed a work plan and piloted the instruments in schools not included in the study. These steps enabled the researcher to effectively carry out the research and the desired sequencing of the steps Kothari, [12]. The permit was presented to the head teachers of the selected schools. It was also used to brief the respondents in order to promote trust with them. The researcher visited respective schools to establish rapport with respondents in preparation for data collection. This helped the researcher to determine a suitable time to administer the questionnaires. The head teachers were the entry point to the selected schools and they introduced the study to the teacher counselors, deputy head teachers, selected members of PA and students who were informed of the study and given research consent forms. The researcher then administered the questionnaires in person. This ensured $100 \%$ return rate of the questionnaires.

\subsection{Collection of Qualitative Data}

Qualitative data was collected through individual interviews, focus group discussions and analysis of documents. The interviews were audio taped so that information about participants' lived experiences would be accurate Creswell [6]. Field notes such as observational notes were used in order to minimize loss of data and to have detailed descriptions of the researcher's observations, reflections and experiences during the research process. Eight focus group discussions each composed of ten students from the schools in the sample were conducted. 32 individual interviews were also conducted as follows; 8 parents, 8 principals, 8 deputies and 8 HODs. The students in the focus groups reported their perceptions pertaining to their parents' attachment styles, their family socioeconomic status and their behavior. The parents were asked about their attachment to their children, their socioeconomic statuses and how these contributed to the behavior of their children. Teachers also gave reports on how socioeconomic status contributed to the relationship between parental attachment and the behavior of the 
students.

\subsection{Results and Discussion}

The study sought to determine the mediative role of family socioeconomic status in the relationship between parental attachment and deviant behavior among secondary school students in Homabay County. To address this objective, the null hypothesis "There is no statistically significant relationship between family socioeconomic status and parental attachment among secondary school students in Homabay County." was tested. The responses on the family SES questionnaire were as shown on table 3 below.

Table 3. Responses on Family Socio-Economic Status.

\begin{tabular}{llll}
\hline Descriptive statistics & & & \\
\hline & N & Mean & Std. Deviation \\
\hline $\begin{array}{l}\text { Finished some primary education } \\
\text { or did not go to school }\end{array}$ & 512 & 1.31 & .461 \\
Finished lower secondary & 512 & 1.18 & .382 \\
Finished form 3 and four & 512 & 1.52 & .519 \\
Finished university or higher & 512 & 1.11 & .316 \\
Finished post secondary but not & 512 & 1.21 & .410 \\
university & & & \\
Has never worked outside the & 512 & 1.56 & .768 \\
home for pay & 512 & 2.33 & .521 \\
Small business owner & 512 & 2.18 & .422 \\
Clerk & 512 & 2.08 & .303 \\
Service or sales worker & 512 & 2.03 & .203 \\
Skilled agricultural worker & 512 & 2.02 & .163 \\
Craft or trade worker & 512 & 2.01 & .107 \\
Plant or machine operator & 512 & 2.10 & .309 \\
$\begin{array}{l}\text { General laborers } \\
\text { Corporate manager or senior }\end{array}$ & 512 & 2.00 & .076 \\
$\begin{array}{l}\text { official } \\
\text { Professional }\end{array}$ & 512 & 2.01 & .107 \\
$\begin{array}{l}\text { Technician or associate } \\
\text { professional }\end{array}$ & 512 & 2.01 & .087 \\
\hline
\end{tabular}

Source; researcher's data

From the responses in Table 3 above majority of the students confirmed that they come from low SES families. This was indicated by the learners who confirmed that their parents are small business owners at a mean of 2.33 , their parents work as clerks at a mean of 2.18 , general laborers at a mean of 2.10 and service or sales workers at a mean of 2.08 . Other learners indicated that their parents are skilled agricultural workers at a mean of 2.03, craft or trade workers at a mean of 2.02, plant operators at a mean of 2.01 and professionals at a mean of 2.01. Further still those who indicated that their parents are technicians were at a mean of 2.01, managers 2.00, have never worked outside the home for pay 1.56 and those whose parents finished form four were at a mean of 1.52 .

The study also found that some parents did not go to school completely at a mean of 1.31 , finished post secondary but not university 1.21 , finished lower secondary at a mean of 1.18 and finally finished university at a mean of 1.11 . These responses were then correlated with their responses on parental attachment style.

Table 4. Responses on Secure Parental Attachment Style.

\begin{tabular}{|c|c|c|c|}
\hline & $\mathbf{N}$ & Mean & Std. Deviation \\
\hline My parents respect my feelings & 512 & 2.70 & .831 \\
\hline My parents accept me as I am & 512 & 3.20 & .672 \\
\hline I trust my parents & 512 & 3.10 & .742 \\
\hline $\begin{array}{l}\text { My parents listen to what I have } \\
\text { to say }\end{array}$ & 512 & 2.51 & .842 \\
\hline My parents care about me & 512 & 3.27 & .703 \\
\hline $\begin{array}{l}\text { I can count on my parents to } \\
\text { help me when I have a problem }\end{array}$ & 512 & 3.02 & .837 \\
\hline $\begin{array}{l}\text { My parents can tell when am } \\
\text { upset about something }\end{array}$ & 512 & 2.78 & .901 \\
\hline $\begin{array}{l}\text { I talk to my parents when I have } \\
\text { a problem }\end{array}$ & 512 & 2.74 & .944 \\
\hline $\begin{array}{l}\text { If my parents know that } \\
\text { something is bothering me, they } \\
\text { ask me about it }\end{array}$ & 512 & 2.85 & .965 \\
\hline $\begin{array}{l}\text { I share my thoughts and feelings } \\
\text { with my parents }\end{array}$ & 512 & 2.39 & .909 \\
\hline $\begin{array}{l}\text { When I am away from home my } \\
\text { parents know where I am and } \\
\text { who I am with }\end{array}$ & 512 & 2.81 & .899 \\
\hline My home is a nice place to live & 512 & 3.18 & .836 \\
\hline My parents pay attention to me & 512 & 2.75 & .845 \\
\hline
\end{tabular}

From the responses in Table 4, parents with secure parental attachment style were evidenced from majority of the students who indicated that their parents accept them as they are with a mean of 3.20. This was also evidenced in another 3.18 who agreed that their home is a nice place to be. Another majority of the students with a mean of 3.10 also indicated that they trust their parents. Also as was indicated by a mean of 2.85 students confirmed that their parents would always ask if they know that something is bothering them. Further the study found that parents who are securely attached to their children usually know where their children are and who they are with. This was indicated by a mean of 2.81. Respondents also confirmed that their parents care about them and can always tell when they are upset with a mean of 2.78 .

The responses further indicated that the parents with secure attachment style can easily tell when their children have a problem with a mean of 2.78 . The study also found out that these parents pay attention to their children (2.75) and their children trust that the parents can help them out with their problems (2.74). It was also revealed that the students who are securely attached to their parents have confidence in their parents and feel that their parents respect their feelings (2.70) and listen to what they have to say (2.51). Finally the respondents also confirmed that they share their thoughts and feelings with their parents with a mean of 2.39 . These responses indicate that the students are comfortable in the presence of their parents and that they consider their parents as friendly people with whom they share their feelings. 
Table 5. Insecure Parental Attachment Questionnaire.

\begin{tabular}{llll}
\hline & N & Mean & Std. deviation \\
\hline $\begin{array}{l}\text { My parents don't understand what I } \\
\text { am going through these days }\end{array}$ & 512 & 2.06 & .877 \\
I get upset easily with my parents & 512 & 2.04 & .967 \\
I feel angry with my parents & 512 & 1.67 & .906 \\
It's hard for me to talk to my parents & 512 & 1.65 & .838 \\
$\begin{array}{l}\text { I feel scared in my home } \\
\text { My parents don't pay attention to me }\end{array}$ & 512 & 1.54 & .843 \\
$\begin{array}{l}\text { at all. } \\
\text { My parents don't appreciate the }\end{array}$ & 512 & 1.78 & .858 \\
things I do. & & 1.85 & .810 \\
\hline
\end{tabular}

Source; Researcher's Data

From the responses in Table 5, students who experience insecure parental attachment affirm that their parents do not understand them and that they easily get upset with their parents. This is confirmed by a mean of 2.06 and 2.04 respectively. Further still some respondents with a mean of 1.85 indicated that their parents do not appreciate anything they do and yet another 1.78 also confirmed that their parents don't pay attention to them at all. The study also found that those with insecure avoidant attachment style are always angry with their parents and find it hard to speak to their parents with a mean of 1.67 and 1.65 respectively. Finally other respondents with a mean of 1.54 feel scared in their homes.

\subsection{Correlation Between Family SES and Parental Attachment}

A correlation analysis was conducted. The set scores on the family socioeconomic status were used as the independent variable while scores from parental attachment questionnaire were used as the explanatory variable (dependant variable). The results of the correlation are presented in Table 6 below.

Table 6. Correlation between Family Socioeconomic Status and Parental attachment.

\begin{tabular}{llll}
\hline & & $\begin{array}{l}\text { Socio-economic } \\
\text { status }\end{array}$ & $\begin{array}{l}\text { Parental } \\
\text { Attachment }\end{array}$ \\
\hline Socio- & Pearson Correlation & 1 & $.714^{* *}$ \\
economic & Sig. (2-tailed) & & .000 \\
status & $\mathrm{N}$ & 512 & 512 \\
& Pearson Correlation & $.704^{* *}$ & 1 \\
Parental & Sig. (2-tailed) & .000 & \\
Attachment & $\mathrm{N}$ & 512 & 512 \\
\hline
\end{tabular}

**. Correlation is significant at the 0.05 level (2-tailed).

The Pearson Product-Moment correlation coefficient ( $\mathrm{r}$ $=.714$ ) revealed a very strong significant positive correlation between family socioeconomic status and parental attachment among secondary school students in Homabay County. This indicates that as the family SES increases, parental attachment styles also change to the positive and subsequently deviant behavior among secondary school students decreases.

The findings of this study are reminiscent to those of Velleymalay [35] who revealed that parental SES has a strong impact on parental involvement. He further opined that low SES families are least likely to be involved in their children's education. Al-Matalka [2] also found that educational level of parents has greater impact on parental involvement than parental occupation and income. Similarly, Wandella [36] reported that poor families often confront multiple stressors which will first affect the emotional lives and marital interactions of adults and then diffuse into the caretaking environment of the children. The findings of this study also corroborate to those of Ferin [9] who revealed a significant interaction between family poverty status and parental discussion as well as Kaur and Verma [11] who also found high prevalence

of abuse in low SES families. Others who also agree with the findings of this study include Ling [14] who revealed that families of lower SES have lower social bonding with their children. Mountney and Reid [18] reported that poor parents strain to provide their children with basic needs and this affects their parenting. Similarly, Yunus and Dahlan [38] reported that attachment of fathers to their children increase with higher SES. Stull [33] revealed that family SES is associated with parents' expectations of their children.

In addition, Schumaker [29] found a significant relationship between child neglect and poverty. Rawatlal et al [26] also reported that higher house hold income families were associated with less anxious attachment relationship and higher maternal education correlated with parental involvement and support. Elgbeleye and Olasupo [8] also revealed that low SES increased chances of child labour. Hamad [10] also concur with the findings of this study as he reported a strong relationship between poverty and child labour. Finally, Mwangi [21] also revealed that parental level of education and income had positive association with their level of participation in preschool education.

\subsection{Qualitative Data Analysis}

In addition to quantitative results, qualitative data revealed varied views concerning the study objective. The students were asked to describe their families, briefly describe their parents, how they relate with their parents and whether this relationship contributed to their behaviour. While they indicated varied closeness and support within their families, most boys when asked to describe their parents, reported that their fathers are bullies while their mothers are friendly. The boys reported that because of the aggression they experience from the fathers they take alcohol and occasionally engage in violence. For example,

"Am forced to take a little on my way home from school in the evening so that when he starts his noise, I don't pay attention or I shut him down." (FGD)

When asked about their relationship with their parents, while majority admitted that they talk to their parents, not all of them were free to share their personal problems with their parents or even share about their boy girl relationships. For example,

"I cannot tell my parents about my boyfriend neither would 
I want them to know that something is bothering me. If my father gets to know that I have a problem, he would start blaming me for the problem. I would rather share with my friends." $(F G D)$

Some students also reported that they fear their parents and cannot sit in one room with them. For example,

"My father is so unpredictable (anaporomoka) that when he comes to the living room, I go to the kitchen. I hate his habit of quarreling with us always. I don't care whether he is proud of me or not because he doesn't care about me." (FGD)

The responses above are indications of insecure attachment between the students and their parents which has resulted to I don't care attitudes towards the parents. However another majority reported cordial relationship with their parents.

"I share a lot with my mother, in fact when I have a problem she is always the first one to know. She encourages me to work hard in school and I do not want to disappoint her." (FGD)

From the response above, the student views the parent as a friend and therefore strives to please the parent by doing the right things. When asked whether their parents support them, quite a number admitted that they can count on their parents to support them whenever they have a problem and that their parents fully take care of them. This was suggested by the following comments;

"My parents pay my school fees, buy me uniform and books and also provide for us while we are at home." "They are always there when I need to talk to them and they make sure they help me in doing what makes me happy." They care about my whereabouts, always want to know who my friends are....... which makes me want to do better in school so as to make them happy."(FGD).

The above respondent exhibits secure attachment with the parents and expresses that because of this she fears indulging in deviant behavior because she does not want to disappoint the parent. When parents were asked about their relationship with their children, their responses indicated varied tones of disappointment, unhappiness, fear, excitement and confidence as described by the following participants.

"Nowadays I don't understand my son, we used to be close but all of a sudden, he changed, ............. he no longer wants to tell me stories as he used to. Partly I blame myself because when he joined class five I took him to boarding school and since then things have not been the same. He prefers to lock himself up in his room most of the times (struggles with tears). He no longer wants to go to church and at times I find him so rude to me................ I destroyed my son's life!'”[Parent 4]

The reflection of the response by parent 4 indicates a disappointment because of the change in the behavior of the child occasioned by the separation. The parent has now lost trust in him and feels that he is becoming deviant (verbal aggression).

My son is a focused boy, very bright in fact that is why he managed to join this school. I trust him fully and I know he is responsible. He aspires to become an ENGINEER. My son and I have a warm relationship, he tells me his problems and I am also free to share with him." Can you imagine when schools close, he squeezes his pocket money and buys me something on his way home [Parent 1].

Parent one exhibits a lot of confidence in her son and has a lot of hope in him. This is as a result of the close attachment between them. From her statement the son has not shown any signs of deviance or else she would have reported that since the son is free to share with her.

"I fear for my daughter. Although she tells me her problems am not sure if she tells me everything. When she is at home she spends more time with her friends than she does with me. One day she sneaked out with her friends in the night. When I asked her, she told me they had gone to watch a movie at a friends' house. I wonder why she could not come to ask for permission or just inform me! [Parent 6]

Parent 6 is concerned about his daughter but he does not know how to help her. He admits that she is deviant and he does not trust her. The two of them are not free with one another and therefore even the girl does not inform him of her whereabouts.

When teachers were asked about parental attachment and deviant behavior, these are some of the responses they gave.

"Some of our parents are so concerned that they do not wait to be called for them to come to school to know about the progress of their children. Although their children are day scholars, they frequent the school and always want to engage the teachers. The irony is that for some of these parents, their children feel that they are over involved and are not happy when they see their parents come to school. Some of these students who do not want their parents to come to school like bunking school and we suspect that they use drugs or have bad friends outside school" [principal 1].

From the response above it is clear that although the parent is concerned about the education of his child, the attachment between the parent and the child is not secure and that is why the child does not appreciate what the parent is doing and hence gets involved in deviant behavior.

Some of these students when they are asked to go home and call their parents, they will plead with you to give them any other form of punishment because their parents will either not come or if the parent comes they will be beaten. Those who say that their parents will not come feel that their parents do not care about them while those who fear that the parent will beat them feel that their parents are too harsh and violent. This does not affect their behavior as such because some of them are disciplined. [Deputy 1]

From what deputy 1 has reported, it is clear that the insecure attachment between these children and their parents does not contribute to their behavior in school. During the interview parents also expressed their opinion on secure parental attachment in poor conditions. Parents unanimously agreed that poor parents actually found it hard to develop close and secure attachment with their children since they are always out in the farm or in the market. The parents were of the opinion that the level of income determined attachment 
style and child's behavior since it determines exposure, presence of the parent at home and availability of personal needs.

\section{Conclusion}

The objective of the study sought to determine the mediative role family socioeconomic status on the relationship between parental attachment and deviant behaviour. The findings revealed a significant positive relationship between SES and parental attachment. These findings imply that if the family socioeconomic status of the residents of Homabay County is improved the parents will be able to cultivate appropriate attachment styles with their children. The findings further tacitly suggest that socioeconomic status mediates the relationship between parental attachment and deviant behavior. This means that family socioeconomic status may dictate the parental attachment style of the parents and consequently determine the behaviour of the child.

\subsection{Recommendation}

Since the findings of the study revealed a significant relationship between family socioeconomic status and parental attachment style, the study came up with the following recommendations;

The County government of Homabay should come up with effective poverty eradication measures in order to improve the living standards of the families in Homabay County. This would even help the parents to put up buildings big enough to accommodate them and their children so that the children do not have to sleep far from their parents. Since low SES is associated with significant risk exposure and low protection factors which are likely to influence behavior, such a program would help curb the problem of the adolescents sneaking out at night to attend disco matangas. The study also recommends that the county government of Homabay should introduce free and active adult education in the County and build such centers within the county. This would ensure lifelong learning for the parents and even the youths who drop out of school to go and get married. In the long run, adult education would enable the parents to expand their knowledge and also to increase their income thus increasing their SES and consequently an improvement in the attachment between the parents and their children which results in positive behavior change among secondary school students in Homabay County.

\subsection{Suggestions for Further Study}

This study has contributed immensely to the existing body of literature on the mediative role of family SES on the relationship between parental attachment and deviant behaviour. The findings revealed a significant relationship between family SES and parental attachment. The study suggests further research on this topic in all the other 46 counties for purposes of comparison.

\section{References}

[1] Akwalu, A. G. M. (2016). Behavioural Effects of Parental Violence on Learners' Academic Performance in Secondary Schools in Tigania East Sub- County of Meru County in Kenya. Developing Country Studies www.iiste.org. Vol. 6, No. ISSN 2224-607X (paper) ISSN 222-50565.

[2] Al-Matalka M. I. F., (2014). Influence of Parental Socioeconomic Status on their Involvement at Home. International Journal of Humanities and Social Science. Vol. 4. No. 5.

[3] Aute A. D., (2019). Secure Parental Attachment and Deviant Behaviour among Secondary School Students in Homabay County- Kenya. Science Journal of Education. Vol. 7, No. 6 pp 127-133.

[4] Borhani, Y. (2013). Substance abuse and insecure attachment styles: a relational study; LUX: A journal of Trans disciplinary Writing and Research from Claremont Graduate University: Vol. 2 Iss. 1 Article.

[5] Bowlby, J. (2008). Attachment. Basic books.

[6] Creswell, J. W. (2012). Qualitative inquiry and research design: choosing among fivemapproaches ( $4^{\text {th }}$ ed.). Thousand Oaks, CA: mSage

[7] Dimbuene, T. Z., \& Defo, K. B. (2010). Risky Sexual Behavior among Unmarried Young People in Cameroon. Another Look at Family Environment. J Biosoc. Sci., 43, 129153 doi: $10.1017 / \mathrm{S} 002 / 93201000063$.

[8] Elgbeleye, O. S. \& Olasupo, O. M. (2011). Parental Socioeconomic Status as Correlate of Child Labour in Ile Ife, Nigeria. Bangladesh e-Journal of Sociology vol. 8 No. 2.

[9] Ferin, F. (2011). The Effect of Family Poverty on Children's Academic Achievement: Parental Discussion and Neighboring Poverty as Mediating Variables.

[10] Hamad, A. H. A. (2013). Parent's Socioeconomic Status with Child Labour Practices in Northern Pemba. The case of Michiweni District-Zanzibar.

[11] Kaur, S., Verma, S. (2015). Socioeconomic status: a determinant of abuse among rural adolescents. The International Journal of Indian Psychology. ISSN 2348-5396 Vol. 2 Iss 2, paper ID: BOO33IV2122015. http://www.ijip.in.

[12] Kothari C. R (2004). Research Methodology: Methods and Techniques. New Age International. ISBN 8122415229, 9788122415223 .

[13] Lim, J. C., Muslihah, H., Sa' Odah, A., \& Wu, S. L. (2013). Parental Attachment, Peer Attachment and Delinquency among Adolescents in Selangor, Malaysia. Asian Social Science Vol. 9, No. 15 ISSN: 1911-2017.

[14] Ling, O. M. (2013). The Relationship between Family Socioeconomic Status and Lifestyle among Youth in Hong Kong. Discovery -SS Student E-Journal Vol. 2: 135-168.

[15] Lincoln, Y. S. \& Guba, E. G. (2005). Naturalistic Inquiry. Newbury Park, CA: Sage Publications.

[16] Mertens, D. M. (2010). Research and Evaluation in Education and Psychology: Integrating Diversity with Quantitative, Qualitative and Mixed Methods. Journal of Mixed Methods Research 4 (1): 3-5. 
[17] Merton, K. Robert (1940). Bureaucratic Structure and Personality. Social Forces, vol. 18, Issue 4: 560-568.

[18] Mountney, K. \& Reid, K. (2012). Parenting on a Low Income. Center for Research on Families and relationships (CRFR) www.aboutfamilies.org.uk.

[19] Mugenda, O. M. \& Mugenda, A. G. (2003). Research Methods; Quantitative and Qualitative approaches. Nairobi African Centre for Technology Studies.

[20] Mutie, J. (2015). Effects of Emotionally Absent Parents on the Behavior of Adolescents in Selected Secondary Schools in Machakos County-Kenya. http://irlibrary.ku.ac.ke/bitstream/handle/123456789/14414.

[21] Mwangi, M. W. (2016). Influence of Parents' Socioeconomic Status on Their Participation in Children's Preschool Education in Kayole, Nairobi. http://irlibrary.kuac.ke/bitstream/handle/123456789/17577.

[22] Ngai, S.S. (2015). Parental Bonding and Character Strengths among Chinese Adolescents in Hong Kong. International Journal of Adolescence and Youth. Vol. 20 issue 3. http://dx.doi.org/10.1080/02673843.2015.1007879.

[23] Ngwiri, B. M., Mukulu, E. J., \& Mputhia, G. J. (2016). Influence of Knowledge Technology Transfer on the Growth of Micro and Small Catering Enterprises in Nairobi County Kenya. International journal of scientific and research publications Vol. 6 Issue 1 ISSN: 2250-3153.

[24] Poipoi, W. M., Agak, O. J. \& Kabuka, K. E. (2011). Perceived Home Factors Contributing to Violent Behavior among Public Secondary School Students in Western Province, Kenya. Journal of Emerging Trends in Educational Research and Policy Studies 2 (1): 30-40. Scholar link research institute journals, 2011 (ISSN: 2141-6990).

[25] Rafiq, W. M. H., Fatima, T., Sohail, M. M., Saleem, M. \& Khan, A. M. (2013). Parental Involvement and Academic Achievement: A Study on Secondary School of Lahore Pakistan. International Journal of Humanities and Social Science vol 3. No. 8. (Special issue-2013).

[26] Rawatlal, N., Pillay, J., Basil \& Kliewer, W. (2015). Socioeconomic Status, Family Related Variables and Caregiver Adolescent Attachment. South African Journal of Psychology. Vol. 45 Issue 4.

[27] Robin, E. Y. (2013). The influence of Parent Child Attachment Relationships and Self Esteem on Adolescents' Engagement in Risky Behaviors.
[28] Sanne, L. A., De V., Hoeve, M., Stams, G. J. J. M., \& Jessica, J. A. (2016). Adolescent Parent Attachment and Externalizing Behavior: The Mediating Role of Individual and Social Factors. Journal of Abnormal Child Psychology 44: 283-294.

[29] Schumaker, K. (2012). An Exploration of the Relationship between Poverty and Child Neglect in Canadian Child Welfare.

[30] Shenton A. K. (2004). Strategies for Ensuring Trustworthiness in Qualitative Research Projects. Education for Information. Vol. 22, No. 2: 63-75.

[31] Simba, O. N., Agak, O. J. \& Kabuka, K. E. (2016). Impact of Discipline on Academic Performance of Pupils in Public Primary Schools in Muhoroni Sub County, Kenya. Journal of Education and Practice ISSN 2222-1735 (Paper) ISSN 2222288X Vol. 7, No. 6: 915326.

[32] Shute J. V., Hansen, G. E., Underwood S. J., \& Razzouk, R. (2011). A Review of the Relationship between Parental Involvement and Secondary School Students' Academic Achievement. Educational Research International. Vol. 2011, ID 915326 doi; $10.1155 / 2011$.

[33] Stull, J. C. (2013). Family Socioeconomic Status, Parent Expectations, and a Child's Achievement. Research in Education. http://dx.doi.org/10.7227/RIE.90.1.4.

[34] Tadesse, G. B., Mitikie, M., Yemane, B., Amenu, W., \&Tesfaye, C. (2016). Determinants of Risky Sexual Behaviour among Preparatory School Students in Gurage Zone, SNNPR, Ethiopia (A Cross-Sectional School Based Study), Science Journal of Public Health. Vol. 4, No. 4, 2016 : 330-341. doi: 10.11648/j.sjph.20160404.2.

[35] Vellymalay, S. K. N. (2012). The Impact of Parent's Socioeconomic Status on Parental Involvement at Home: A Case Study on High Achievement Indian Students of a Tamil School in Malaysia. International journal of academic research in business and social sciences. Vol. 2, No. 8 ISSN 2222-6990.

[36] Wandella, W. (2015). Parenting in Poverty: Inequity through the Lens of Attachment and Resilience. American International Journal of Social Science Vol. 4 No. 2 ISSN 23254149 (Print) 2325-4165 (online). www.aijssnet.com.

[37] Yesu, L. \& Hardwood, A. E. L. (2015). Effects of Parental Involvement, Support and Pressure on Athletic Participation. River Academic Journal vol. 11, number 1.

[38] Yunus, M. R. K., \& Dahlan, A. N. (2013). Child-Rearing Practices and Socioeconomic Status: Possible Implications for Children's Educational Outcomes. Procedia-Social and Behavioural Sciences 90 (2013): 251-259. 